\title{
Reproductive efficiency of adult and prepubertal goats subjected to repeated follicular aspiration
}

\author{
[Eficiência reprodutiva em cabras adultas e pré-púberes após repetidas sessões \\ de aspiração folicular] \\ M.F. Cordeiro, P.P.M. Teixeira, M.E.F. Oliveira, P.A. Di Filippo, D.P.M. Dias, \\ C.A.G. Beretta, R.G.S. Dória, M.A.R. Feliciano*, \\ L.N. Coutinho, W.R.R. Vicente \\ Universidade Estadual de São Paulo - Jaboticabal, SP
}

\begin{abstract}
The objective of this study was to assess the reproductive response of adult and prepubertal goats subjected to repeated laparoscopic ovum pick-up (LOPU). The study animals were divided into two groups, specifically, adult nanny goats $(\mathrm{GA}, \mathrm{n}=10)$ and prepubertal nanny goats $(\mathrm{GP}, \mathrm{n}=10)$, which were subjected to estrous synchronization and ovarian stimulation for LOPU. Both groups underwent six LOPU procedures at seven-day intervals and were subsequently subjected to controlled mating and pregnancy diagnosis to evaluate their future fertility. The study showed a reduction in the number of follicles visualized and in the amount and quality of the oocytes that were recovered and exposed to in vitro maturation. As indicated by the fertility test, however, no complications were found during the laparoscopic procedures that would impair the reproductive future of the animals. Therefore, a viable number of oocytes were obtained even with the decreased reproductive efficiency, proving that repeated LOPUs do not interfere with the reproductive of adult and prepubertal nanny goats. These results indicate a positive aspect of this procedure, allowing for increasing reproductive performance of this kind, when used for the production in vitro.
\end{abstract}

Keywords: goat, laparoscopy, follicular puncture, oocyte recovery

\section{RESUMO}

O objetivo deste estudo foi avaliar a resposta reprodutiva de cabras adultas e pré-púberes submetidas a repetidas aspirações foliculares por videolaparoscopia (LOPU). Os animais do estudo foram divididos em dois grupos, especificamente cabras adultas $(G A, n=10)$ e pré-púberes $(G P, n=10)$, que foram submetidas a sincronização de estro e estimulação ovariana para LOPU. Ambos os grupos foram submetidos a seis procedimentos LOPU em intervalos de sete dias e foram posteriormente submetidos à monta controlada e posterior diagnóstico de gestação para avaliar sua fertilidade. $O$ estudo mostrou uma diminuição do número de folículos visualizados, na quantidade e na qualidade dos oócitos que foram recuperados e expostos à maturação in vitro. Tal como indicado pelo teste de fertilidade, no entanto, não foram observadas grandes complicações durante os procedimentos laparoscópicos que pudessem prejudicar o futuro reprodutivo dos animais. Portanto, foi obtido um número de oócitos viáveis, mesmo com a diminuição da eficiência reprodutiva, provando que repetidas $L O P U$ não interferem na reprodutividade de animais adultos e pré-púberes. Estes resultados indicam um aspecto positivo desse procedimento, possibilitando um aumento da eficiência reprodutiva dessa espécie quando utilizado para a produção in vitro.

Palavras-chave: caprino, laparoscopia, punção folicular, recuperação oocitária

Recebido em 8 de outubro de 2012

Aceito em 30 de julho de 2013

*Autor para correspondência (corresponding author)

E-mail: marcusfeliciano@yahoo.com.br 


\section{INTRODUCTION}

Laparoscopic ovum pick-up (LOPU) was first described by Snyder and Dukelow (1974). When this method is combined with in vitro production (IVP), LOPU can produce a large number of viable offspring in a short time (Baldassarre et al., 2002; Wani, 2002; Cognié et al., 2004).

Ultrasound-guided ovum pick-up (OPU) for oocyte recovery in live females is frequently performed in cattle. The technique is still quite limited in small ruminants, however, making it a difficult procedure for even experienced veterinarians to perform in addition to causing more trauma than laparotomy or laparoscopy. Laparotomy inevitably causes some degree of surgical trauma, and extreme care is needed to prevent the formation of postoperative adhesions (Basso et al., 2008). These consequences make laparotomy unsuitable for medium- and longterm use, especially in females of high genetic value (Freitas and Simplício, 2002).

Conversely, laparoscopy is less invasive, allows faster recovery and can be performed several times in the same female, which make it an outstanding procedure. Recently, this technique has been used in vivo to obtain oocytes for use in basic research and in vitro for producing embryos in small ruminants (Baldassarre et al., 2002).

Laparoscopy is highly efficient because it can be used repeatedly over short intervals, but studies evaluating the effect of repeatedly using the technique on reproductive efficiency have been restricted to sheep (Stangl et al., 1999; Teixeira et al., 2011) and cattle (Pieterse et al., 1991; Becker et al., 1996; Santl et al., 1998; Viana et al., 2003).

It is imperative to obtain information on the response of adult and prepubertal nanny goats to ovarian stimulation and oocyte recovery rate protocols following repeated LOPU procedures. Therefore, the objective of this study was to evaluate the reproductive response of adult and prepubertal nanny goats exposed to repeated LOPUs.

\section{MATERIALS AND METHODS}

The experiment was conducted at the School of Agricultural and Veterinary Sciences, São Paulo State University "Julio de Mesquita Filho" (Universidade Estadual Paulista "Julio de Mesquita Filho"), which is located in the municipality of Jaboticabal (latitude $21^{\circ} 15^{\prime} 17^{\prime \prime S}$ and longitude $48^{\circ} 19^{\prime} 20^{\prime \prime} \mathrm{W}$ and at an altitude of 605 m.s.l), in the state of São Paulo, Brazil.

The Animal Ethics and Welfare Committee of the School of Agricultural and Veterinary Sciences of the São Paulo State University system approved this study (under protocol no. 025922-08). The principles of the European Ethics Committee for research involving animals were also observed.

Twenty crossbred nanny goats breed were divided into two groups according to age: the adult group (GA, n=10), which included pluriparous adult animals aged two to three years, and the prepubertal group (GP, n=10), which included animals aged six to eight months. All the animals were subjected to six LOPU with an interval of seven days between procedures. The animals had a mean body condition score (BCS) of 3.0+0,25 (on a scale from 1-5, from Jefferies, 1961) and were considered eligible to undergo the study protocol after a clinical examination that included total protein and fibrinogen assays, a complete blood count and parasite control. The goats were kept under an intensive management system, receiving corn silage and a balanced feed twice per day and $a d$ libitum access to water and mineral salt.

For estrous synchronization, animals were treated with intravaginal sponges impregnated with $60 \mathrm{mg}$ of medroxyprogesterone acetate (MAP - Progespon $®$, Schering-Plough, Brazil), starting at a random day of the estrous cycle (Day 0) and for a total of 6 days. On day nine (D9), $37.5 \mu \mathrm{g}$ of D-cloprostenol (Sincrocio®) Ourofino S.A., Brazil) was administered.

For all of the subsequent aspirations, the ovaries were stimulated with 300 IU of eCG (Novormon ${ }^{\circledR}, \quad$ Schering-Plough, Brazil) and $80 \mathrm{mg}$ of FSHp (Schering-Plough, Brazil) administered intramuscularly $12 \mathrm{~h}$ after the D-cloprostenol administration and $36 \mathrm{~h}$ before the LOPU. 
After being deprived of food for $36 \mathrm{~h}$ and water for $24 \mathrm{~h}$, the animals were given $0.05 \mathrm{mg} / \mathrm{kg} / \mathrm{IM}$ of $2 \%$ xylazine hydrochloride (Vallée, Brazil) as a premedication. After $10 \mathrm{~min}$, induction was performed using $10 \%$ ketamine hydrochloride at a dose of $2 \mathrm{mg} / \mathrm{kg} / \mathrm{IV}$. Anesthesia was maintained with a continuous infusion of $50 \mathrm{mg} / \mathrm{mL}$ of $5 \%$ guaiacol glyceryl ether [GGE (Guaifenesin, Henrifarma, Brazil)], $0.1 \mathrm{mg} / \mathrm{mL}$ of $2 \%$ xylazine hydrochloride and $1 \mathrm{mg} / \mathrm{mL}$ of $10 \%$ ketamine hydrochloride diluted in $500 \mathrm{~mL}$ of a normal saline solution containing $5 \%$ dextrose and infused at a rate of $2 \mathrm{~mL} / \mathrm{kg} / \mathrm{h}$ or 10 to 15 drops/min according to the anesthesia protocol. Before total intravenous anesthesia (TIVA), the animals underwent tracheal intubation to avoid aspiration of their ruminal contents in case of regurgitation and to allow the supply of humidified medical oxygen under assisted ventilation to facilitate gas exchange.

In the surgical area, hair clipping and skin antisepsis with iodine were performed on the abdominal region rostral to the udder, and local infiltration anesthesia with $0.4 \mathrm{~mL} \quad(0.2 \mathrm{~mL}$ subcutaneous and $0.2 \mathrm{~mL}$ intramuscular) of lidocaine hydrochloride (Bravet, Brazil) was subsequently administered.

The animals were placed in the Trendelenburg position, and a $\mathrm{CO}_{2}$ pneumoperitoneum (with a pressure range of 5 to $8 \mathrm{mmHg}$ and a flow rate of $2.5 \mathrm{~L} / \mathrm{min}$ ) was established using a Veress needle introduced approximately 10 to $15 \mathrm{~cm}$ cranial to the udder and five centimeters to the right of the midline.

The procedure was performed using two laparoscopic portals, with the first trocar (Trocar Karl Storz, diameter $7.0 \mathrm{~mm}$, length 10.5 comprising: Shutter pyramidal shirt without valve with insufflation tap and multi-function valve, H. Strattner \& Cia Ltda, São Paulo, Brazil) introduced at the needle site and the second trocar (likewise the first) introduced into the lateral antimere. The laparoscope $\left(0^{\circ}\right.$ and $7 \mathrm{~mm}$, H. Strattner \& Cia Ltda, São Paulo, Brazil) and a Babcock atraumatic forceps (7mm, H. Strattner \& Cia Ltda, São Paulo, Brazil) were introduced through these trocars.

The forceps were used to immobilize the ovaries and the visible on the surface were aspirated using a $16 \mathrm{G}$ needle with a short bevel protected by a plastic sheath transcutaneously (Angiocath BD®, São Paulo, Brazil), coupled to a $50 \mathrm{mmHg}$ vacuum pressure system (Handle Cook®, Ribeirão Preto, Brazil). To minimize adhesion formation, the ovaries were washed with approximately $20 \mathrm{~mL}$ of harvesting medium (heparin in PBS - $5000 \mathrm{IU} / \mathrm{mL}$ diluted with 0.1 of solution). Skin suture was performed using horizontal "U-shaped" suture pattern. Next, the surgical wound was cleaned with povidone iodine and a repellent/healing ointment was used around the wound. Surgical time was measured and possible complications during the procedure. Females were placed in a clean and calm environment and were observed until standing in all four legs. On the subsequent interventions, incisions were made laterally to the first.

In the case of apparent pain, the animals were treated with flunixin meglumine $1.1 \mathrm{mg} / \mathrm{kg}$ intramuscularly (Banamine $\AA$, Schering-Plough, Brazil).

The aspirated fluid was taken to the laboratory, and the oocytes present were recorded and classified. These oocytes subsequently underwent in vitro maturation 100 to $200 \mu \mathrm{L}$ of wash medium and taken to culture plates containing $100 \mathrm{~mL}$ of maturation medium under mineral oil where they remained for 27 hours in an oven at $39^{\circ} \mathrm{C}$ and $5.0 \% \mathrm{CO}_{2}$ atmosphere. At the end of cultivation, all oocytes were denuded under a stereomicroscope (50-80x) in washing medium with automatic pipette to $100 \mathrm{~mL}$ at ambient temperature $\left(28^{\circ} \mathrm{C}\right)$. Afterwards, they were fixed for 5 min with $4 \%$ formamide in PBS and permeabilized with $1 \%$ Triton in PBS for 10 min. Then, the oocytes were stained with gel Mowiol included dye Hoechst 33342, fixed between slide and cover slip, sealed with enamel, and taken to the microscope epifluorescência16 after the minimum time of 24 hours for observation of nuclear maturation stage.

The recovered oocytes were categorized according to the adapted classification of Leibfried and First (1979): Grade I (complete cumulus complex), Grade II (more than two layers of cumulus cells), Grade III (one layer of cumulus cells or incomplete cumulus) and Grade IV (nude and/or damaged oocyte). Grades I to III were classified as viable. In all of the viable oocytes, the cytoplasm was expected to have a homogeneous appearance and bright coloration. 
After the maturation step, the oocytes were classified according to the system of Wang et al. (2002). The oocytes were considered to be mature when the formation of an axis during metaphase with expulsion of the first polar body was observed, and the oocytes were considered to be immature when the metaphase plate was not observed.

To test the reproductive integrity of the experimental animals after the last LOPU, the GA underwent estrous synchronization and controlled mating (at least two matings per animal). The same procedure was followed for the GP, but only after they reached reproductive age. Pregnancy detection by ultrasound was performed 45 days after mating.

The data visualized follicles (VF), aspirated $(\mathrm{AF})$, oocytes retrieved (OR), oocyte recovery rate (TR) - percentage of oocytes retrieved per follicle aspirated, viable oocytes (VO) - grade I to III, mature oocyte (MO) were analyzed using analysis of variance (ANOVA) with the statistical package SAS ${ }^{\circledR}$ (User's Guide: Statistics, 1985). The means were compared using Tukey's test $(\mathrm{P}<0.05)$. Fertility was evaluated using the chi-square test.

\section{RESULTS}

The procedures were performed without any major complications, and each procedure lasted 35 minutes on average (46- 23 minutes for GA and 49 - 23 minutes to GP, maximum and minimum). Bleeding on the surface of the ovaries caused by follicular puncture was minimal; in addition, washing the ovaries and removing any large clots at the end of each procedure largely prevented adhesion formation. Thus, only $15 \%$ of the animals (3/10 to GA and $3 / 10$ to GP) had any adhesions between the ovary and adjacent structures, predominantly after the fourth intervention, and only $10 \%$ (2/10 to GA and $2 / 10$ to GP) developed adhesions between the omentum and the insertion sites of the trocars.

On the third day after the surgery, the skin lesions on most of the animals showed good healing. Only $10 \%$ of the cases (2/10 to GA and $2 / 10$ to GP) showed local inflammation.

The number of follicles and quality of the oocytes in the GA decreased $(p<0.05)$ over the course of the study; the total number of follicles visualized and aspirated, number of oocytes recovered and recovery rate for each group over the six weeks are shown in Table 1.

Despite the short interval between interventions and the designated fasting period (36h without food), the animals did not experience a significant decrease in body weight over the six sessions and experienced a net weight gain by the end of the experiment $(\mathrm{p}>0.05)$, shown in Figure 1.

Table 1 . The ovum pick-up date from the adult and prepubertal nanny goats

\begin{tabular}{cccccccccc}
\hline $\begin{array}{c}\text { LOPU } \\
\text { Procedure }\end{array}$ & Group & $\mathrm{n}$ & $\mathrm{VF}$ & AF & OR & VO & MO & MR & TR \\
\hline $1^{\text {st }}$ & GA & 10 & $220 \mathrm{a}$ & $150 \mathrm{a}$ & $7.80 \pm 0.83 \mathrm{a}$ & $7.40 \pm 0.72 \mathrm{a}$ & $4.70 \pm 0.64 \mathrm{a}$ & $63.5 \mathrm{a}$ & $52.00 \mathrm{a}$ \\
& GP & 10 & $196 \mathrm{~b}$ & $137 \mathrm{~b}$ & $5.30 \pm 0.72 \mathrm{~b}$ & $4.60 \pm 0.79 \mathrm{~b}$ & $2.80 \pm 0.47 \mathrm{~b}$ & $60.8 \mathrm{a}$ & $38.68 \mathrm{~b}$ \\
$2^{\text {nd }}$ & GA & 10 & $194 \mathrm{a}$ & $147 \mathrm{a}$ & $6.40 \pm 0.89 \mathrm{a}$ & $5.80 \pm 0.75 \mathrm{c}$ & $3.70 \pm 0.60 \mathrm{c}$ & $63.8 \mathrm{a}$ & $86.48 \mathrm{c}$ \\
& GP & 10 & $178 \mathrm{~b}$ & $116 \mathrm{~b}$ & $4.90 \pm 0.95 \mathrm{c}$ & $3.50 \pm 0.95 \mathrm{~d}$ & $2.10 \pm 0.71 \mathrm{~b}$ & $60.0 \mathrm{a}$ & $42.24 \mathrm{~b}$ \\
$3^{\text {rd }}$ & GA & 10 & $174 \mathrm{~b}$ & $141 \mathrm{a}$ & $6.90 \pm 0.79 \mathrm{a}$ & $6.20 \pm 0.70 \mathrm{c}$ & $4.30 \pm 0.92 \mathrm{a}$ & $69.3 \mathrm{a}$ & $48.93 \mathrm{a}$ \\
& GP & 10 & $141 \mathrm{c}$ & $101 \mathrm{c}$ & $5.50 \pm 0.98 \mathrm{~b}$ & $4.00 \pm 0.71 \mathrm{~b}$ & $3.00 \pm 0.50 \mathrm{~b}$ & $75.0 \mathrm{~b}$ & $54.45 \mathrm{a}$ \\
$4^{\text {th }}$ & GA & 10 & $174 \mathrm{~b}$ & $116 \mathrm{~b}$ & $5.50 \pm 0.80 \mathrm{~b}$ & $4.00 \pm 0.70 \mathrm{~b}$ & $2.50 \pm 0.49 \mathrm{~b}$ & $62.5 \mathrm{a}$ & $47.41 \mathrm{~b}$ \\
& GP & 10 & $139 \mathrm{c}$ & $98 \mathrm{c}$ & $5.50 \pm 0.81 \mathrm{~b}$ & $4.90 \pm 0.82 \mathrm{~b}$ & $3.20 \pm 0.67 \mathrm{c}$ & $65.3 \mathrm{a}$ & $56.12 \mathrm{a}$ \\
$5^{\text {th }}$ & GA & 10 & $135 \mathrm{c}$ & $97 \mathrm{c}$ & $6.00 \pm 0.46 \mathrm{~b}$ & $4.50 \pm 0.92 \mathrm{~b}$ & $3.50 \pm 0.75 \mathrm{c}$ & $77.8 \mathrm{~b}$ & $61.85 \mathrm{a}$ \\
& GP & 10 & $114 \mathrm{~d}$ & $85 \mathrm{~d}$ & $4.10 \pm 0.69 \mathrm{c}$ & $3.20 \pm 0.85 \mathrm{~d}$ & $2.80 \pm 0.56 \mathrm{~b}$ & $87.5 \mathrm{c}$ & $48.23 \mathrm{a}$ \\
$6^{\text {th }}$ & GA & 10 & $108 \mathrm{e}$ & $70 \mathrm{~d}$ & $3.60 \pm 0.83 \mathrm{~d}$ & $2.60 \pm 0.72 \mathrm{e}$ & $1.90 \pm 0.54 \mathrm{~d}$ & $73.1 \mathrm{~b}$ & $51.42 \mathrm{a}$ \\
& GP & 10 & $123 \mathrm{~d}$ & $83 \mathrm{~d}$ & $4.60 \pm 0.83 \mathrm{c}$ & $3.80 \pm 0.72 \mathrm{~d}$ & $2.70 \pm 0.54 \mathrm{~b}$ & $71.0 \mathrm{~b}$ & $55.42 \mathrm{a}$ \\
\hline
\end{tabular}

$\mathrm{GA}=$ Adult nanny goats; $\mathrm{PG}=$ Prepubertal nanny goats; $\mathrm{n}=$ animal number; Recovery rate $(\%)=$ No. of aspirated follicles/no. of oocytes recovered; $\mathrm{VF}=$ Visualized follicles; $\mathrm{AF}=$ Aspirated follicles; $\mathrm{OR}=$ Oocytes recovered; $\mathrm{VO}$ $=$ Viable oocytes $; \mathrm{MO}=$ Mature oocytes $; \mathrm{MR}=$ Maturation rate. $\mathrm{TR}=$ Recovery rate $(\%)$-no. of aspirated follicles/no. of oocytes recovered. Equal letters in each column $\mathrm{p}>0.05$; Different letters in each column, $\mathrm{p}<0.05$. 


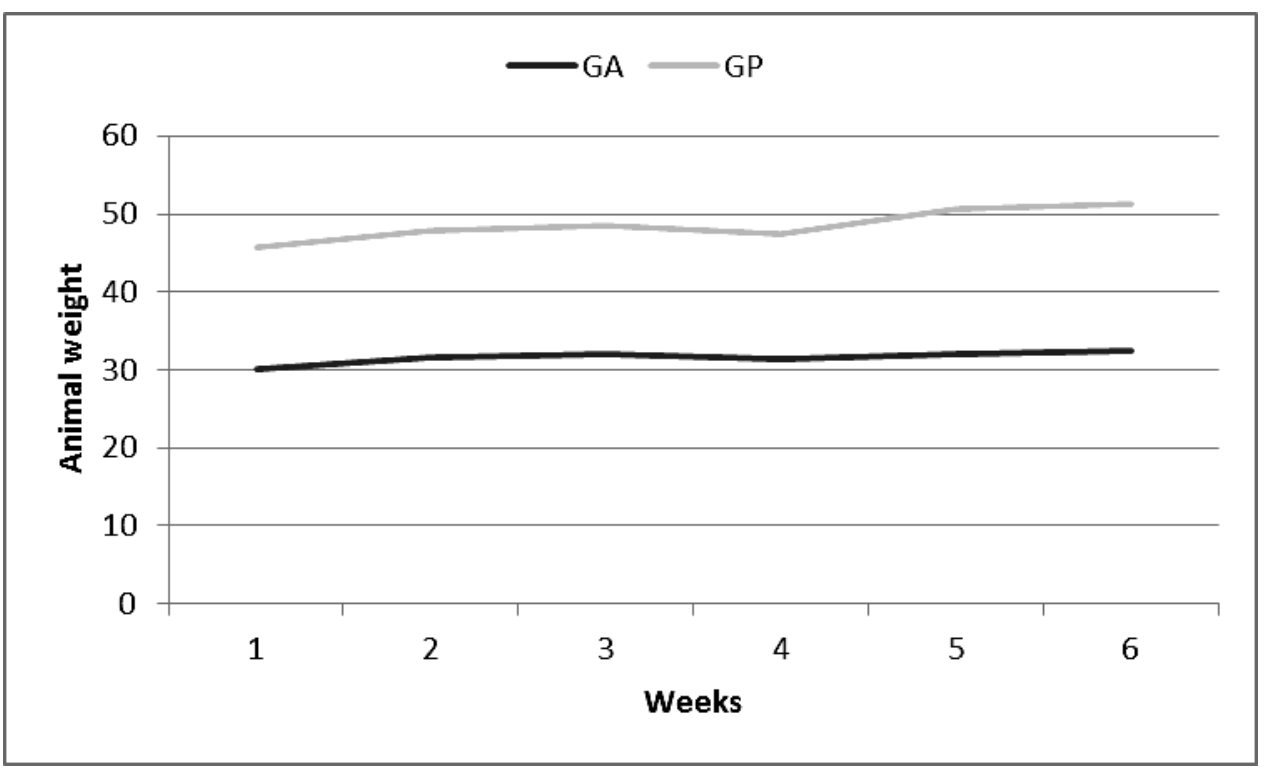

Figure 1. Graphical representation of the weight of the experimental animals. GA = adult goats and GP = prepubertal goats.

The pregnancy rates of the animals after the repeated LOPU procedures were $44.44 \%$ (4 out of 9 nanny goats) and $60.00 \%$ (6 out of 10 nanny goats) for the GA and GP, respectively.

\section{DISCUSSION}

In addition to avoiding reflux of the ruminal contents in most of the procedures, fasting for $36 \mathrm{~h}$ and a pneumoperitoneum of 5 to $8 \mathrm{mmHg}$ helped to establish adequate manipulation and visualization of the abdominal cavity. The tracheal tube helped to maintain assisted respiration and to avoid aspiration of the ruminal contents in case of reflux. Ruminal reflux has been reported as a complication in sheep subjected to laparoscopy, even after being deprived of food for $72 \mathrm{~h}$ and water for $24 \mathrm{~h}$ (Bittencourt et al., 2004). We attributed the regurgitation of ruminal contents to the pneumoperitoneum and to intravenous anesthesia with ketamine and acepromazine. However, this complication was not relevant in this study because of the low incidence of regurgitation and the lack of intraoperative and postoperative complications.

The average surgical time was $35 \mathrm{~min}$, which was similar to the times described by Teixeira et al. (2011) (26.75 $\pm 9.6 \mathrm{~min})$ and Wieczorek et al. (2010) (18 to 20min) during follicular aspirations in sheep. Duarte et al. (2009) reported an average time of $23 \mathrm{~min}$ for liver biopsies in sheep, and Bleul et al. (2005) required 120 to $150 \mathrm{~min}$ for ovariectomies in cows. These reports indicate that the laparoscopic technique allows performing different procedures quickly, especially in small ruminants. Nevertheless, veterinary skill is important to obtain this result, as has also been noted by the authors mentioned above.

The surgical technique used in this study allowed excellent post-surgical recovery of the animals. The seven-day interval used between interventions was sufficient to allow for oocyte recovery without compromising the clinical condition of the animals, as evidenced by the increased body condition score of the animals. Teixeira et al. (2011) and Stangl et al. (1999) obtained similar results in sheep; the former evaluated both the body condition score and behaviors associated with pain and discomfort, while the latter did not report any clinical or behavioral observations.

Washing the punctured ovaries with harvesting medium (heparin in PBS) was effective for preventing adhesion formation between them and other structures, such as the uterus, fallopian tubes and ovarian bursa; however, one animal developed an adhesion between the right ovary and the bladder after the second laparoscopy. Tabet et al. (2005) have stated that 
possible intraoperative accidents, especially organ laceration, may occur due to trocar positioning, and according to Duarte et al. (2009), this procedure requires the use of a Veress cannula.

Several of the young animals had full bladders during the intervention, making it difficult to visualize and grasp the ovaries. Teixeira et al. (2011) have referred to manipulating the reproductive system, ovary immobilization and follicular puncture as the greatest difficulties faced when performing the procedure. Nevertheless, the distension of the abdominal cavity due to the pneumoperitoneum and the 10time magnification of the transmitted video image made the procedures easier and resulted in rapid completion of the surgical procedures.

The average number of follicles per animal found in this experiment was similar to those described by Baldassare and Karatzas (2004), who reported 13.4 follicles/animal, and Basso et al. (2008), who obtained 14.3 follicles/animal. Furthermore, the rate of oocyte recovery in prior studies were within 40 to $90 \%$ (Cognié et al., 2004; Morton et al., 2005; Rodriguez et al., 2006; Cox and Alfaro, 2007; Gibbons et al., 2007).

Oocyte production decreased, both quantitatively and qualitatively, over the course of the repeated LOPU sessions. Roy et al. (1999), De Ruigh et al. (2000) and Drion et al. (2001) have mentioned the hypothesis of antibody formation resulting from prolonged use of exogenous hormones, such as anti-eCG and anti-FSH, which may compromise oocyte recovery. The likelihood of inducing FSH antibody formation is increased in goats treated with porcine $\mathrm{FSH}$, thereby decreasing the ovarian response after the third application (Remy et al., 1991), which would result in treatment failure. Nevertheless, in adult sheep stimulated with eCG and FSH and subjected to nine LOPU sessions, Teixeira et al. (2011) found an absence of variation in the number and quality of aspirated oocytes; therefore, goats may have different responses from sheep.

Another hypothesis considers that approximately $10 \%$ of nanny goats are not responsive to superovulation treatment (Brebion et al., 1992). Although alternative techniques (such as ovum pick-up combined with in vitro embryo production) exist, superovulation is still an effective and inexpensive procedure to maximize the number of offspring from genetically superior females (Driancourt 2001).

Even with a decrease in the follicular aspiration reproductive indices, the number of procedures was reproductively viable for producing and maturing oocytes in both groups. Broadbent et al. (1997) have noted that in vivo oocyte aspiration and in vitro embryo production may increase the number of embryos produced in the time available if the procedures can be performed frequently and successfully.

No significant differences were found between the reproductive indices of the different age group ( $>>0.05)$. Similar results have been observed in adult sheep subjected to three ovum pick-up procedures with an interval of 14 days between sessions, which results in more follicles and recovered oocytes in stimulated females. However, the harvesting rates from prepubertal and adult females are similar $(\mathrm{p}>0.05)$ between the treatments (Stangl et al., 1999; Morton et al., 2005).

The pregnancy data suggest no fertility impairment in either the adult or prepubertal nanny goats. These results are similar to those seen in adult and prepubertal sheep subjected to repeated LOPU procedures (Stangl et al., 1999; Valasi et al., 2006). Therefore, this technique is considered suitable for use in female goats and does not affect their reproductive life.

\section{CONCLUSION}

Even with the reduction in reproductive efficiency observed after repeated LOPU procedures, a viable number of oocytes for the goat species were obtained. In addition, the repeated LOPUs apparently did not interfere with the future reproduction of the adult and prepubertal nanny goats; therefore, this LOPU technique may be used to increase the efficiency of in vitro reproduction in this species.

\section{ACKNOWLEDGMENTS}

The authors would like to thank the São Paulo State Research Foundation (Fundação de Apoio a Pesquisa e Ensino do Estado de São Paulo FAPESP) for financially supporting this project. 


\section{REFERENCES}

BALDASSARE, H.; KARATZAS, C.N. Advanced assisted reproduction technologies (ART) in goats. Anim. Reprod. Sci., v.82, p.255266, 2004.

BALDASSARRE, H.; WANG, B.; KAFIDI, $\mathrm{N}$. et al. Advances in the production and propagation of transgenic goats using laparoscopic ovum pick-up and in vitro embryo production technologies. Theriogenology, v.57, p.275-284, 2002.

BASSO, A.C.; MARTINS, J.F.P.; FERREIRA, C.R. et al. Biotecnologia da reprodução na espécie ovina: produção in vitro de embriões ovinos: aspectos da técnica de aspiração folicular e do tratamento hormonal de doadoras [biotechnology of reproduction in sheep: in vitro production of sheep embryos: aspects of follicular aspiration technique and hormonal treatment of donors. $O$ Embrião, v.38, p.8-11, 2008.

BECKER, F.; KANITZ, W.; NURNBERGm G. et al. Comparison of repeated transvaginal ovum pick up in heifers by ultrasonography and endoscopic instruments. Theriogenology, v.46, p.999-1007, 1996.

BITTENCOURT, R.H.F.P.M.; SILVA, M.C.; MOREIRA, V.M.S. et al. Observações sobre o uso de cetamina, acepromazina e halotano em ovelhas submetidas a procedimentos laparoscópicos [Observations on the use of ketamine, acepromazine and halothane in ewes subjected to laparoscopic procedures. Rev. Bras. Med. Vet., v.26, p.150-154, 2004.

BLEUL, U.; HOLLENSTEIN, K.; KÄHN, W. Laparoscopic ovariectomy in standing cows. Anim. Reprod. Scie., v.90, p.193-200, 2005.

BREBION, P.; BARIL, G.; COGNIÉ, Y. et al. Embryo transfer in sheep and goat. Ann. Zoot., v.41, p.331-339, 1992.

BROADBENT, P.J.; DOLMAN, D.F.; WATT, R.G. et al. Effect of frequency of follicle aspiration on oocyte yield and subsequent superovulatory response in cattle. Theriogenology, v.47, p.1027-1040, 1997.
COGNIÉ, Y.; POULIN, N.; LOCATELLI, Y. State-of-the-art production, conservation and transfer of in vitro produced embryos in small ruminants. Reprod. Fert. Develop., v.16, p.437445, 2004.

COX, J.F.; ALFARO, V. In vitro fertilization and development of OPU-derived goat and sheep oocytes. Reprod. Domes. Anim., v.42, p.83-87, 2007.

DE RUIGH, L.; MULLAART, E.; VAN DE WAGTENDONK, A.M. et al. The effect of FSH stimulation prior to ovum pick-up on oocyte and embryo yield. Theriogenology, v.53, p.429, 2000.

DRIANCOURT, M.A. Regulation of ovarian follicular dynamics in farm animals. Implications for manipulation of reproduction. Theriogenology, v.55, p.1211-1239, 2001.

DRION, P.V.; FURTOSS, V.; BARIL, G. et al. Four years of induction/synchronization of estrus in dairy goats: effect on the evolution of eCG biding rate in relation with parameters of reproduction. Reprod. Nutr. Dev., v.41, p.401412, 2001.

DUARTE, A.L.L.; CATTELAN, J.W.; BEZERRA, M.B. et al. Biópsia hepática com agulha tru-cut guiada por videolaparoscopia em caprinos [Video laparoscopic guided hepatic biopsy with tru-cut needle in goats. Arq. Bras. Med. Vet. Zootec., v.61, p.12-19, 2009.

FREITAS, V.J.F.; SIMPLÍCIO, A.A. Transferência de embriões em caprinos. In: GONÇALVES, P.B.D.; FIGUEIREDO, J.R.; FREITAS, V.J.F. (Eds.) Biotécnicas Aplicadas à Reprodução Animal, São Paulo: Livraria Varela, 2002. p.179194.

GIBBONS, A.; PEREYRA BONNET, F.; CUETO, M; A procedure for maximizing oocyte harvest for in vitro embryo production in small ruminants. Reprod. Domes. Anim., v.42, p.423426, 2007.

JEFFERIES, B.C. Body condition scoring and its use in management. Tasmanian J. Agricult., v.32, p.19-21, 1961.

LEIBFRIED, L.; FIRST, N.L. Characterization of bovine follicular oocytes and their ability to mature in vitro. J. Anim. Sci., v.48, p.76-86, 1979. 
MORTON, K.M.; DE GRAAF, S.P.; CAMPBELL, A. et al. Repeat Ovum Pick-up and In Vitro Embryo Production from Adult Ewes with and without FSH Treatment. Reprod. Domes. Anim., v.40, p.422-428, 2005.

PIETERSE, M.C.; VOS, P.L.A.M.; KRUIP, T.A.M.; et al. Transvaginal ultrasound-guided follicular aspiration of bovine oocytes. Theriogenology, v.35, p.19-24, 1991.

REMY, B.; BARIL, G.; VALLET, J.C. et al. Are antibodies responsible for a decreased superovulatory response in goats which have been treated repeatedly with porcine follicle stimulating hormone? Theriogenology, v.36, p.389-399, 1991.

RODRÍGUEZ, C.; ANEL, L.; ALVAREZ, M. et al. Ovum Pick-up in Sheep: a Comparison between Different Aspiration Devices for Optimal Oocyte Retrieval. Reprod. Domes. Anim., v.41, p.106-113, 2006.

ROY, F.; MAUREL, M.C.; COMBES, B. The negative effect of repeated equine chorionic gonadotropin treatment on subsequent fertility in Alpine goats is due to a humoral immune response involving the major histocompatibility complexes. Biol. Reprod., v.60, p.805-813, 1999.

SANTL, B.; WENIGERKIND, H.; SCHERNTHANER, W. et al. Comparison of ultrasound-guided vs. laparoscopic transvaginal ovum pick-up (OPU) in Simmental heifers. Theriogenology, v.50, p.89-100, 1998.

SAS user's guide: statistics, Volume 2 de SAS User's Guide: Version 5 Edition. SAS Institute, 1985, 956p.

SNYDER, D.A.; DUKELOW, R. Laparoscopic studies of ovulation, pregnancy diagnoses, and follicle aspiration in sheep. Theriogenology, v.2, p.143-148, 1974.
STANGL, M.; KUHHOLZER, B.; BESENFELDER, U. et al. Repeated endoscopic ovum pick-up in sheep. Theriogenology, v.52, p.709-716, 1999.

TABET, A.F.; SILVA, L.C.; SHINHORINI, I.L.; Comparison between two techniques of laparoscopic-assisted renal biopsy in equines. Braz. J. Vet. Res. Anim. Sci., v.42, p.150-156, 2005.

TEIXEIRA, P.P.M; PADILHA, L.C.; MOTHEO, T.F. et al. Laparoscopic ovum collection in sheep: Gross and microscopic evaluation of the ovary and influence on oocyte production. Anim. Rep. Sci., v.127, p.169-175, 2011.

VALASI, I.; MENEGATOS, I.; PAPANIKOLAOU, T.H. et al. Oocyte pick-up in juvenile lambs affects neither onset of puberty nor their future fertility. Theriogenology, v.66, p.2144-2151, 2006.

VIANA, J.H.M.; NASCIMENTO, A.A.; PINHEIRO, N.N.L. et al. Caracterização de sequelas subsequentes à punção folicular em bovinos [Characterization of tissue damages after ovum pick-up in bovine. Pesq. Vet. Bras., v.23, p.119-124, 2003.

WANG, B.; BALDASSARRE, H.; TAO, T.; Transgenic goats produced by DNA pronuclear microinjection of in vitro derived zygotes. Mol. Reprod. Dev., v.63, p.437-443, 2002.

WANI, N.A. In vitro maturation and in vitro fertilization of sheep oocytes. Small Rum. Res., v.44, p.89-95, 2002.

WIECZOREK, J.; KOSENYUK, Y.; CEGŁA, M. et al. A new concept in laparoscopic ovum pick-up (OPU) in sheep - efficiency of method and morphology of recovered oocytes. Ann. Anim. Sci., v.10, p.39-48, 2010. 